\title{
ECONOMIC POTENTIAL OF AGRO-FOOD PRODUCTION IN THE REPUBLIC OF SERBIA
}

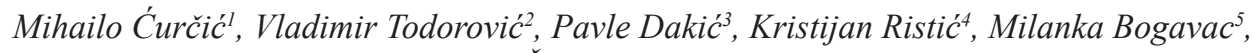
Marko Špiler ${ }^{6}$, Milovan Rosic ${ }^{7}$

*Corresponding author E-mail: curcicmihailo@gmail.com

\begin{abstract}
A R T I C L E I N F O
Original Article

Received: 12 April 2021

Accepted: 23 August 2021

doi: 10.5937/ekoPolj2103687C

UDC 338.1:631.15(497.11)

Keywords:

competitiveness, trade structure, comparative advantage, $R C A$, Lafay's and GL Index

JEL: F13, P52, Q17

\section{A B S T R A C T}

This research conducted a structural and analysis of the foreign trade position of the Republic of Serbia, with special emphasis on agricultural and food products, in order to provide detailed information regarding current trends, measuring the level of comparative advantage and international position in the world and European markets. The obtained results indicate the elements that have a limiting effect on the development of this type of production. Using the RCA Index methodology and the Lafay's Index, the link between the food industry and the character of industrial exchange was established, which is measured by the Grubel Lloyd's Index. The structure of exports was analyzed from the aspect of factor intensity, so the existence of negative values of a comparative advantage and intensive goods was confirmed. Finally, we believe that the results obtained have contributed to the unraveling of available instruments, the eventual efficient use of which would help rural development, and thus the overall economic development of the Republic of Serbia.
\end{abstract}

(C) 2021 EA. All rights reserved.

1 Mihailo Ćurčić, PhD, Assistant Professor / Research Associate, University of Defense, Pavla Jurišića Šturma 33, 11000, Belgrade, Serbia, +381654009049, e-mail: curcicmihailo@, gmail.com, ORCID ID (https://orcid.org/0000-0001-7674-0310)

2 Vladimir Todorović, PhD, Asst. Prof., University MB, Prote Mateje 21, 11000, Belgrade, Serbia, +381643224329, e-mail: vladimir.todorovic@ppf.edu, ORCID ID (https://orcid. org/0000-0001-9794-9527)

3 Pavle Dakić, PhD student, University for Business Studies, Jovana Dučića 23a, 78000, Banja Luka, Bosnia and Herzegovina, +421919486878, e-mail: pavledakic@yahoo.com, ORCID ID (https://orcid.org/0000-0003-3538-6284)

4 Kristijan Ristić, PhD, Assoc. Prof., University MB, Prote Mateje 21, 11000, Belgrade, Serbia, +38163267127, e-mail: kristijanristic.fpim@yahoo.com, ORCID ID (https://orcid. org/0000-0001-8907-1304)

5 Milanka Bogavac, PhD, Asst. Prof., University MB, Prote Mateje 21, 11000, Belgrade, Serbia, +381646597028, e-mail: milanka.bogavac@ppf.edu, ORCID ID (https://orcid. org/0000-0003-4252-6919)

6 Marko Špiler, PhD, Assoc. Prof., Faculty of Management, Njegoševa 1a, 21205, S. Karlovci, Serbia, +381642480025, e-mail: mspiler@cmn.rs, ORCID ID (https://orcid.org/0000-0001-6319-2597)

7 Milovan Rosić, Ministry of Health of the Republic of Serbia, Save Kovačevića 7, Kragujevac, Serbia, E-mail: rosic.milovan@gmail.com, ORCID ID (https://orcid.org/0000-0003-3153-2117) 


\section{Introduction}

Dealing with the research of the competitiveness of the domestic economy in relation to European and world developed countries, it actually represents a detailed and structural analysis of macroeconomic, as well as microeconomic, indicators. When it is said that the economy of a certain country is a competitor, then it refers to competition in improving productivity in accordance with the modernization of existing technology, but also the application of new technologies. Moreover, development directly affects the creation of new added value and innovation, but also the proper and efficient economic development of the entire macroeconomic environment. (Popescu et al., 2017) Analyzing Proag's research (2014), it can be established that global economic competitiveness is the result of a relatively new economic paradigm, whose name has become widespread in the last decade - a sustainable economy. In this regard, it is necessary to link multiple concepts of competitiveness and competitiveness at the national level. (Rose and Liao, 2005). Rutkauskas (2008) argues that a competitive economy makes the most efficient use of available resources, which are in fact its main elements of competitiveness. The process of improving the production factors is actually improving competitiveness, with the aim of increasing economic activity, which requires a larger volume of investment in the economy and a focus on its production oriented as foreign trade.

Authors IIlmaz and Ergun (2003) analyzed the comparative advantage of exports in EU candidate countries, in order to more precisely define international activity. In that sense, Ferto and Hubart (2002) point out the necessary changes in the structure of agriculture, and then in the food industry, which would not be possible without state support. Similarly, Serin and Civan (2008), Erlat and Erlat (2012), as well as Toming (2008) point out the factors of non-price competitiveness in the market in modern conditions. As the essence lies in product quality, investments in product development are urgently needed to achieve their desired level of comparative advantage. Also, recent research provides similar findings: Ceilan et al. (2018) in their analysis claim that even in conditions of pronounced competition in the market, it should be intensified with the export of products with high added value.

According to Andrei et al. (2020) agricultural trade is a way to achieve the full national agricultural potential in highly competitive modern economies. Similarly, BrodovskaSzevczuk (2019) stated that the main instruments of competitiveness are the implementation of new products or services, as well as improving the quality of these products and services. If we talk about Serbia, in their earlier research, Ignjatijević et al. (2012) considered the competitiveness of the food industry. Concluding that it is only partially competitive, the authors conclude that the existence of a comparative advantage with a negative sign is a consequence of inefficiently solved or completely unsolved problems, which arose in the long process of transition and oscillations in production quality.

The first part of the paper includes an introduction to the research issues, with reference to previous research, the importance of previous results, some of which are used below as a 
reference basis in the acquired knowledge. Furthermore, after the presented methodology used in the research, and a brief description of macroeconomic parameters (2016 to 2020), we have analyzed the results which are obtained in the research. In the concluding part, we have summarized the aim of this article as well as scientific contribution of it.

\section{Literature Preview}

On the other hand, although Gechabia et al. (2019) investigated the elements of innovative marketing that is applied in agribusiness, it should be noted that the starting points were formed precisely on the economic stimulation of foreign trade, and its impact on the development of the food sector within agriculture.

Monaco et al. (2017) in their paper refer to the monitoring and study of the combination of the Market Orientation Index (MOI) and the Economic Balance Index (EBI), based on which the typical characteristics of agro-food systems in Western countries are confirmed, which are strong specialization in developed sectors, mainly by allocating products to global markets, and others that are more or less targeted at local and regional markets. However, based on the evidence presented in this paper, reconnecting and adjusting food supply and demand may be at odds with broader economic improvements in regional production. At the same time, measuring the economy with current values and market prices fails to adequately capture the effects of non-market goods and values on regional economic sustainability, which are not proposed in the assessment - such as healthy food or clean rivers.

The modern food market directs the development of organic production. It is defined by many factors, among which distrust in genetically modified products should be singled out; health risks that arise in mass production; promoting environmental technologies in production; organic production (Sapic et al, 2018; Voronkovoa et al., 2019; Poltarikhin et al., 2018; Vujić et al, 2019). Observed from the aspect of ecologically acceptable and economically viable potential of the region, which bases its production on organic agricultural production, it is possible to expand the volume of production and improve the level of competitiveness (Korableva et al., 2018). However, the development of sustainable economic mechanisms plays a key role in this endeavor.

When it comes to testing data using the RCA Index, in the example of Bulgaria, Ignjatijević et al. (2021) presented a high share of food products in the export of this country of the country, which contributed to the creation of a positive value of comparative advantage. The study of the results of the comparative advantage of the export sector as a whole, but also only of the food sector, points to the following: the comparative advantage of the export sector as a whole indicates a reduction of RCA Index in 2017, ten years after the accession of Bulgaria to the EU.

According to Đukić et al. (2017) high levels of RCA Index, Revealed Competitiveness (RC) Index, and Additive Revealed Comparative (ARCA) Index for Serbia show significant competitive advantages of the agro-food sector. These values are higher than in neighboring countries which are members of the European Union, and they are 
the result of a significant share of agriculture in GVA (gross value added), as well as the high share of exports of agricultural products. In contrast, the export structure of agro-food products from Serbia is unfavorable (raw materials and products with a small degree of processing).

Đukić et al. (2020) stated that Serbian foreign trade indicates an unfavorable structure of exports when it comes to agricultural and food products. The structure of exports, in which raw materials, i.e. primary agricultural products, dominate, is a feature of the underdeveloped agricultural sector. In order to improve foreign trade and ensure a higher foreign exchange inflow, a consistent and stimulating agricultural policy is necessary (Tasić, 2018), as well as greater investment in the food sector. In that way, capacities would be provided for overcoming the existing and future challenges faced not only by the primary agricultural production but also by the food industry, as its logical continuation.

\section{Methodology and Materials}

As previously stated, this paper will analyze the structure of merchandise exports of the food industry of the Republic of Serbia, classified into five categories of agricultural products. Special attention is paid to processed and fresh food, in accordance with the methodology of the International Trade Center (ITC), which would help to obtain the valid results in calculating the comparative export advantage of this product category.

The classification of agricultural products, whose data are the subject of the research, was performed on the basis of defined categories and exceptions, previously conducted by Hufbauer and Chilas (1974), according to their technological nature (Table 1).

Table 1. Standard International Trade Classification

\begin{tabular}{|c|c|c|c|}
\hline \multirow{2}{*}{ Category } & \multicolumn{2}{|c|}{ Notes } & \multirow{2}{*}{ Abbreviation } \\
\hline & Serial No. & Exception & \\
\hline $\begin{array}{l}\text { Raw material-intensive } \\
\text { goods }{ }^{8}\end{array}$ & $0,2,3,4,56$ & $2(26), 3(35)$ & RIMG \\
\hline $\begin{array}{l}\text { Labour intensive } \\
\text { goods }^{9}\end{array}$ & $26,6,8$ & $6(62,67,68), 8(87,88)$ & LIG \\
\hline $\begin{array}{l}\text { Capital-intensive } \\
\text { goods }^{10}\end{array}$ & $1,3,53,55,62,67,68,78$ & - & $\mathrm{CIG}$ \\
\hline
\end{tabular}

$8 \quad 0$ Food and Live Animals; 2 Crude Material, Inedible, Except Fuels (excluding 26); 3 Mineral Fuels, Lubricants and Related Materials (excluding 35); 4 Animal and Vegetable Oils, Fats and Waxes; 56 Fertilizers (other than those of group 272)

926 Textile Fibers (other than wool tops and other combed wool) and their wastes (not manufactured into yarn or fabric), 6 Manufactured Goods Classified by Material (excluding 62, 67, 68);8 Miscellaneous Manufactured Articles (excluding 88, 87)

101 Beverages and Tobacco; 35 Electric Current; 53 Dyeing, Tanning and Coloring Materials; 55 Essential Oils and Resinoids and Perfume Materials,. Toilet Polishing and Cleaning Preparations; 62 Rubber Manufactures, n.e.s.; 67 Iron and Steel; 68 Non-Ferrous Metals; 78 Road Vehicles (including Air-Cushion Vehicles) 


\begin{tabular}{|c|c|c|c|}
\hline \multirow{2}{*}{ Category } & \multicolumn{2}{|c|}{ Notes } & \multirow{2}{*}{ Abbreviation } \\
\hline & Serial No. & Exception & \\
\hline $\begin{array}{l}\text { Easy-to-imitate research- } \\
\text { intensive goods }{ }^{11}\end{array}$ & $51,52,54,58,59,75,76$ & - & EIRG \\
\hline $\begin{array}{l}\text { Difficult -to-imitate research- } \\
\text { intensive goods }{ }^{12}\end{array}$ & $57,7,87,88$ & $7(75,76,78)$ & DIRG \\
\hline
\end{tabular}

Source: SITC / Revision 4, 2006

Benchmarking is a useful tool in the process of examining economic flows, which will be used to compare the relative costs of production and identify the sectors and markets that are most likely to succeed. The comparative analysis will be performed using the RCA index (Revealed Comparative Advantage). The RCA index will be used to determine the most important destinations and product groups for export trade in the region. In the international economy, it is used to calculate the relative advantage or disadvantage of a particular country in a particular class of goods or services.

RCA most commonly refers to the index introduced by Balassa (1965):

$\mathrm{RCA}=\left(E_{i j} / E_{i t}\right) /\left(E_{n j} / E_{n t}\right)$

where $E$ is export, $i$ is the country index, $n$ is the set of countries, $j$ is the commodity index and $t$ is the set of commodities; That is, the RCA is equal to the share of the country's exports belonging to the product class under consideration (Eij / Eit) divided by the share of world exports belonging to that class $\left(E_{n j} / E_{n t}\right)$. A comparative advantage is discovered if $\mathrm{RCA}>1$. If $\mathrm{RCA}<1$, there is not discovered comparative advantage in goods or industry of a country (Granabetter, 2016).

$$
\mathrm{RCA}=\ln \left[\frac{X i}{M i}\right] \times\left[\frac{\sum_{i=1}^{n} X i}{\sum_{i=1}^{n} M i}\right] \times 100
$$

In the above formula, $X$ means the value of exports, and $M$ means the value of imports. Index $i$ denotes the pharmaceutical sector as a whole or its products. In case the state specializes in the production of pharmaceutical products and has a surplus in foreign trade, the RCA indicator has positive values and indicates a comparative advantage.

1151 Organic Chemicals; 52 Inorganic Chemicals; 54 Medicinal and Pharmaceutical Products; 58 Plastics in Non-Primary Forms; 59 Chemical Materials and Products, n.e.s.; 75 Office Machines and Automatic Data-Processing Machines; 76 Telecommunications and SoundRecording and Reproducing Apparatus and Equipment

1257 Plastics in Primary Forms; 7 Machinery and Transport Equipment (excluding 75, 76, 78); 87 Professional, Scientific and Controlling Instruments and Apparatus, n.e.s.; 88 Photographic Apparatus, Equipment and Supplies and Optical Goods, n.e.s.; Watches and Clocks 
The level of specialization in intra-industry exchange was analyzed and defined using the Grubel Lloyd index (GLI). Higher values of the GL index indicate domestic trade, and lower values of the index indicate that foreign trade is of an interindustrial nature. GLI is calculated according to the following (Grubel and Lloyd, 1975):

$$
G L_{i}^{t}=\left(\left(\sum_{i=1}^{n}\left(X_{i}^{t}+M_{i}^{t}\right)-\sum_{i=1}^{n}\left|X_{i}^{t}-M_{i}^{t}\right|\right) / \sum_{i=1}^{n}\left(X_{i}^{t}+M_{i}^{t}\right)\right.
$$

where $G L_{i}^{t}$ presents a interindustrial trade index of sector $i$ in year $t$, while $X_{i}^{t}$ presents goods export of group $i$ in a year $t$, and finally $M_{i}^{t}$ presents the goods import of product's group $i$ in a year $t$.

The Lafay's index (LFI) was used with the aim of a detailed analysis of the values of the comparative advantage index. (Lafay, 1992):

$$
L F I_{j}^{i}=100\left(\frac{x_{j}^{i}-m_{j}^{i}}{x_{j}^{i}+m_{j}^{i}}-\frac{\sum_{j=1}^{N}\left(x_{j}^{i}-m_{j}^{i}\right)}{\sum_{j=1}^{N}\left(x_{j}^{i}+m_{j}^{i}\right)}\right) \frac{x_{j}^{i}+m_{j}^{i}}{\sum_{j=1}^{N}\left(x_{j}^{i}+m_{j}^{i}\right)}
$$

if $x$ are products' export values and $m$ are products' import values.

This index is often used to define the general position of different industrial sectors. The creator of LFI believes that it compensates for the shortcomings of the Balassa index.

The macroeconomic environment of the Republic of Serbia has undergone significant changes in the period after 2010. Given that there is economic growth, but also attempts to privatize and restructure state and public administration, a number of reforms have been launched, fiscal and monetary, in order, among other things, to achieve adequate liberalization of foreign trade, and efficient use of resources that Serbia disposes.

It is estimated that the total economic activity in the Republic of Serbia in 2020, measured by the real movement of gross domestic product, recorded a decline of $1.1 \%$ compared to 2019. In 2020, agricultural production achieved a growth of physical volume of $4.4 \%$, while industrial production, in the same period, recorded an increase in physical volume of $0.2 \%$.

In 2018 , the share of agriculture was $6 \%$ of total GDP, comparing to $1.5 \%$ of the Euro Area. In the surrounding countries, the share of agriculture is higher than in the EU: in Croatia 2.9\%, Bosnia and Herzegovina 5.6\%, Slovenia 2\%, Hungary 3.3\%, Romania $4 \%$ and Bulgaria $3.2 \%$. 
Table 2. Basic Indicators of Macroeconomic Trends in Serbia (2016 - 2020)

\begin{tabular}{|l|c|c|c|c|c|}
\hline \multicolumn{1}{|c|}{ Indicators } & $\mathbf{2 0 1 6}$ & $\mathbf{2 0 1 7}$ & $\mathbf{2 0 1 8}$ & $\mathbf{2 0 1 9}$ & $\mathbf{2 0 2 0}$ \\
\hline Total GDP (\%) & 3.3 & 2.1 & 4.5 & 4.2 & -1.0 \\
\hline GDP per capita (\$) & 5,756 & 6,308 & 7,245 & 7,410 & 7,657 \\
\hline Foreign trade (mil. \$) & $-4,016$ & $-4,923$ & $-6,644$ & $-7,098$ & $-6,735$ \\
\hline GDP of agriculture (bill. \$) & 2,8 & 2,7 & 3,2 & 3,1 & - \\
\hline Agriculture \% in total GDP & 6.8 & 6.0 & 6.3 & 6.0 & - \\
\hline Food industry \% in total GDP & 25.9 & 24.4 & 24.4 & - & - \\
\hline Foreign direct investments (bill. \$) & 2,4 & 2,9 & 4,1 & 4,3 & 3,5 \\
\hline Unemployment rate (\%) & 15.9 & 14.1 & 13.3 & 10.9 & 9.0 \\
\hline Inflation rate (\%) & 1.1 & 3.1 & 1.9 & 1.9 & 1.6 \\
\hline
\end{tabular}

Source: Statistical Office of the Republic of Serbia; World Bank Data

In Serbia, the real growth rate in the agricultural sector was $-11.4 \%$ in $2017,15.1 \%$ in 2018 and $-1.6 \%$ in 2019 regarding a food production index (2004-2006=100), Romania is a country that recorded the best values among southeast European countries (125.52), according to the World Bank Data in 2019. Other countries of the region had similar but worse results: Serbia (105.97), Croatia (104.66), Bulgaria (103.74), Slovenia (102.88), Hungary (101.61).

Resources intended for rural development, as well as scientific-technological development, are emerging as key solutions to sustainable economic development, while also further subsidizing factors that are not seemingly crucial, such as improving rural infrastructure or improving rural farms. Taking into account that in the overall result of foreign trade, Serbia has a constant deficit, over the years, it should be noted that trade in agricultural and food products is among the few categories in which it has a surplus. In 2019, growth was achieved in the amount of 361 million USD, in the category of food products, beverages and tobacco. In the period from 2016 to 2020, the average value of exports of this type of product was 1,424.6 million USD. Positive results were recorded as a consequence of the successful foreign trade to European Union market, and to the countries of the region, as well as a favorable trade position with the EFTA countries.

Effective reforms in the field of a country's national economy provide a certain kind of stability and a good starting point for increasing the living standards of the people living in it. Similarly, as in all other economic activities, modernization and application of innovations is necessary in the agro-economy sector. There are a number of indicators that do not positively affect the competitiveness of products intended for export. Among them are outdated technical equipment, inefficient use of available resources in agricultural production, but lack of raw materials in the production process, so the logical solution is efficient modernization and flexibility in the requirements of the foreign market.

The analysis established a decrease in production in the manufacturing industry by $2.6 \%$ in the observed period. The increase in the volume of production is present in the categories of clothing and footwear and raw materials, ie the decrease in the categories of motor vehicles and fuels. 
Table 3. Basic Indices of Industrial Production, by Activity (Index, $2015=100$ )

\begin{tabular}{|l|c|c|c|c|c|}
\hline \multicolumn{1}{|c|}{ Indicators } & $\mathbf{2 0 1 6}$ & $\mathbf{2 0 1 7}$ & $\mathbf{2 0 1 8}$ & $\mathbf{2 0 1 9}$ & $\mathbf{2 0 2 0}$ \\
\hline Total Industrial Production & 105.2 & 109.3 & 110.7 & 111.0 & 111.5 \\
\hline Manufacture of Food Products & 105.6 & 105.3 & 103.1 & 98.8 & 101.3 \\
\hline
\end{tabular}

Source: Statistical Office of the Republic of Serbia

In order to effectively achieve the desired level of competitiveness in the international market, it is necessary to apply modern engineering, with adequate experience and knowledge in the field of technology use.

Table 4. Exports and imports, by SITC commodity groups, rev.4 (\$ mil.)

\begin{tabular}{|c|l|c|c|c|c|c|}
\hline \multicolumn{2}{|c|}{ Indicators } & $\mathbf{2 0 1 6}$ & $\mathbf{2 0 1 7}$ & $\mathbf{2 0 1 8}$ & $\mathbf{2 0 1 9}$ & $\mathbf{2 0 2 0}$ \\
\hline \multirow{2}{*}{ Export } & Food and Live Animals & 2,267 & 2,292 & 2,422 & 2,584 & 2,944 \\
\cline { 2 - 7 } & Beverages and Tobacco & 550 & 496 & 539 & 583 & 690 \\
\hline \multirow{2}{*}{ Import } & Food and Live Animals & 1,091 & 1,270 & 1,469 & 1,546 & 1,763 \\
\cline { 2 - 7 } & Beverages and Tobacco & 308 & 315 & 345 & 382 & 365 \\
\hline
\end{tabular}

Source: Statistical Office of the Republic of Serbia

Looking at the presented data, we can see the surplus that the Republic of Serbia realizes in foreign trade in primary products. The increased volume of trade, as well as the mentioned liberalization of trade relations with the countries in the region and Europe, have influenced the achievement of a higher level of comparative advantage, and thus competitiveness on the international market.

Table 5. Exports and imports, by products SITC (\$ mil.)

\begin{tabular}{|c|c|c|c|c|c|c|}
\hline \multicolumn{2}{|c|}{ Indicators } & $\mathbf{2 0 1 6}$ & $\mathbf{2 0 1 7}$ & $\mathbf{2 0 1 8}$ & $\mathbf{2 0 1 9}$ & $\mathbf{2 0 2 0}$ \\
\hline \multirow{4}{*}{ Export } & RIMG & 3,280 & 3,518 & 3,854 & 4,019 & 4,403 \\
\cline { 2 - 7 } & LIG & 3,267 & 3,801 & 4,217 & 4,398 & 4,216 \\
\cline { 2 - 7 } & CIG & 20,601 & 24,014 & 27,693 & 28,057 & 10,024 \\
\cline { 2 - 7 } & EIRG & 13,318 & 16,056 & 18,627 & 19,079 & 8,338 \\
\cline { 2 - 7 } & DIRG & 8,189 & 10,422 & 12,279 & 12,553 & 6,207 \\
\hline \multirow{4}{*}{ Import } & RIMG & 3,763 & 4,772 & 5,654 & 5,862 & 4,868 \\
\cline { 2 - 7 } & LIG & 3,415 & 3,886 & 4,437 & 4,582 & 4,732 \\
\cline { 2 - 7 } & CIG & 28,411 & 33,093 & 38,853 & 39,935 & 12,225 \\
\cline { 2 - 7 } & EIRG & 16,933 & 19,370 & 22,809 & 23,724 & 10,789 \\
\cline { 2 - 7 } & DIRG & 9,985 & 11,764 & 19,925 & 14,757 & 5,810 \\
\hline
\end{tabular}

Source: Statistical Office of the Republic of Serbia

Judging by the results, CIG, EIRG and DIRG products account for over $75 \%$ of total exports, while RIMG and LIG products account for $25 \%$, although even a small share of total exports tends to increase in the observed period.

The essence of agricultural production is to increase the volume of production in order to achieve market competitiveness. The increase in the volume of production can be realized through modern knowledge, but also through the influence of foreign capital. If we look at productivity from the ecological aspect, according to its level of production 
capacities, ie the yield that is realized per one production unit, then it should be pointed out that the great importance of the organization of production, with the mentioned application of technological innovations, is constant investment in gaining experience and knowledge.

\section{Results and Discussions}

In this research, the comparative advantage of food products exports in the observed period from 2016 to 2020 was measured. This comparative analysis of manufacturing industry exports established a negative value of the RCA index, while positive values are recorded by products within the food sector. The production of food, beverages and tobacco, but also the production of rubber and plastic products represents a potential that should be used to improve the position on the international market.

On the other hand, the analysis of the RCA index tells us that in 2018 (0.46). year, the level of comparative advantage of the observed product category was higher compared to 2016 (0.13). Obviously, the highest value of the index is recorded in the category of production of food, beverages and cigars, within the processing industry, which significantly affects the realization of the surplus in foreign trade. Consequently, the level of competitiveness of the food industry on the international market has increased. However, in this period, certain oscillations in the values of the observed parameters are also noticeable. This may be a consequence of the change in the volume of trade in goods, but also definitely a consequence of the Covid-19 pandemic in 2020. Deficiencies and imperfections of the system and organization of production in individual segments influenced the emergence of poor results of the entire agro-industry.

Table 6. RCA, LFI and GLI values

\begin{tabular}{|c|c|c|c|c|c|}
\hline RCA & $\mathbf{2 0 1 6}$ & $\mathbf{2 0 1 7}$ & $\mathbf{2 0 1 8}$ & $\mathbf{2 0 1 9}$ & $\mathbf{2 0 2 0}$ \\
\hline Processing industry & $-0,29$ & $-0,27$ & $-0,19$ & $-0,26$ & $-0,17$ \\
\hline Food products and beverage & 0,24 & 0,31 & 0,48 & 0,62 & 0,46 \\
\hline LAF & $\mathbf{2 0 1 6}$ & $\mathbf{2 0 1 7}$ & $\mathbf{2 0 1 8}$ & $\mathbf{2 0 1 9}$ & $\mathbf{2 0 2 0}$ \\
\hline Processing industry & 5,94 & 6,08 & 12,10 & 0,29 & 11,43 \\
\hline Food products and beverage & 5,14 & 4,90 & 5,43 & 4,90 & 5,74 \\
\hline GL & $\mathbf{2 0 1 6}$ & $\mathbf{2 0 1 7}$ & $\mathbf{2 0 1 8}$ & $\mathbf{2 0 1 9}$ & $\mathbf{2 0 2 0}$ \\
\hline Processing industry & 0,67 & 0,73 & 0,79 & 0,82 & 0,84 \\
\hline Food products and beverage & 0,73 & 0,69 & 0,52 & 0,57 & 0,58 \\
\hline
\end{tabular}

Source: Authors' Calculation

The LFI indicates an increase in the comparative advantage, but also an increase in the volume of exports of the food production in 2019. Moreover, using the GLI we can observe a correlation between the comparative advantages of the particular product category in the industry. It should be noted here that changes in the structure of trade affected the specificity of foreign trade in 2016, in contrast to which in 2020 a significant shift was achieved in the production process. 
The prices of export products influenced the improvement of the comparative advantages of the exports of the Republic of Serbia. Favorable price competitiveness, together with increased production volumes, contributed to the improvement of the comparative advantage. Products such as wheat flour, but also other mill products have an extremely high value of the RCA index. As a consequence of the reduction of livestock, ie the constant reduction of investments in animal husbandry, the Republic of Serbia has lost its significance over time when it comes to the international trade in raw pork and beef. However, to some extent, the lack of production of animal raw materials has been replaced by increased production of plant products. Thus, for example, beer and confectionery products increased the value of the RCA index. Similarly, fishing is an aspect of production that is insufficiently represented in the agro-industry of the Republic of Serbia, and which abounds in potential, starting from ecologically favorable environmental conditions and unpolluted running and standing waters, where it is possible to grow fish stock for export.

Table 7. The Empirical Results

\begin{tabular}{|l|c|c|c|c|c|c|}
\hline \multirow{2}{*}{ Indicator } & \multicolumn{2}{|c|}{ RCA } & \multicolumn{2}{c|}{ LAF } & \multicolumn{2}{c|}{ GL } \\
\cline { 2 - 7 } & $\mathbf{2 0 1 6}$ & $\mathbf{2 0 1 9}$ & $\mathbf{2 0 1 6}$ & $\mathbf{2 0 1 9}$ & $\mathbf{2 0 1 6}$ & $\mathbf{2 0 1 9}$ \\
\hline RIMG & $-0,33$ & $-0,36$ & 1,16 & $-0,60$ & 0,54 & 0,67 \\
\hline LIG & $-0,29$ & $-0,20$ & 1,72 & 2,50 & 0,58 & 0,81 \\
\hline CIG & $-0,25$ & $-0,22$ & 3,01 & 2,04 & 0,63 & 0,79 \\
\hline EIRG & $-0,58$ & $-0,73$ & $-2,48$ & $-3,33$ & 0,29 & 0.41 \\
\hline DIRG & $-0,55$ & $-0,42$ & $-3,51$ & $-1,25$ & 0,31 & 0,62 \\
\hline
\end{tabular}

Source: Authors' Calculation

It is possible to single out some of the most important interpretations of the results obtained in the conducted research, which can be systematized according to the following:

- The research resulted in a negative RCA index in categories of RIMG, LIG, CIG, EIRG, and DRIG;

- During the observed time period, the value of the RCA index in foreign trade for the product categories EIRG and RIMG was depreciated. Although this negative trend appears in other categories, the Republic of Serbia has a solid position in relation to other sectors of production;

- Although there is an increase in the volume of merchandise exports in all the mentioned product categories, compared to competitors in the region, the position of the Republic of Serbia is still not at the desired level. Considering that the best positioned product categories are EIRG and DRIG, here is also the greatest space for further development and progress;

- Table 6 intentionally presents the data concluding with 2019, in order for the empirical results to be credible, taking into account the Covid-19 pandemic, which negatively affected all parameters, in 2020 and ongoing. 
Table 8. RCA index of products export

\begin{tabular}{|l|c|c|c|}
\hline \multicolumn{1}{|c|}{ Sectors } & RCA in 2016 & RCA in 2020 & $\Delta$ RCA \\
\hline Fresh Food & -0.14 & 0.00 & 0.14 \\
\hline Processed Food & 0.16 & 0.28 & 0.12 \\
\hline
\end{tabular}

Source: Authors' Calculation

Differentiation of products and production processes in the observed sectors creates a certain level of demand for these products in the regional, European and world markets. The main indicator and fact according to which domestic production should be directed is that products with a positive RCA index create a positive foreign trade balance.

\section{Conclusions}

Research of this kind indicates the existence of the interrelation of the mentioned indices with economic growth and development, but also a very important correlation of inadequate organization and lag behind the developed countries of the European Union. Low agricultural yields are a consequence of the action of many factors, such as low investments, not only in the form of cash inflows, but also the inflow of knowledge, technology and their implementation into the existing production system. The basic values of production, purchase and processing on domestic farms are devalued, and insufficiently high agricultural subsidies discourage producers from finding their perspective in this sector. As previously mentioned, this is a type of problem at the microeconomic level of the Republic of Serbia, however, at the same time acting on the environment in which we live and create, allows further development of the problem, and creating a disadvantaged macroeconomic position at the international level.

The supply of food products of the agro-industry is variable, and for search engines, with a large number of consumers, it is often insufficient. Most products do not have quality certificates, so the production procedure cannot be considered competent, nor can its products. It would be said that small investments in international marketing lead to uncertain placement in foreign markets, and in such a business environment it is difficult to increase competitiveness.

At the strategic level, the adjustment of the export structure to the needs on the import side should be carried out. Also, it is necessary to create an adequate agro-economic policy, with realistically considered possibilities and opportunities on the one hand, but weaknesses and market as well as trade risks on the other hand. Larger budget allocations are needed for the agricultural sector, but the implementation of incentive policies that would keep the population in the countryside and motivate them to continue with agricultural production. Above all, it is necessary to improve the quality of products, as well as harmonize quality with prescribed international standards, in order for products to be competitive and recognizable in the region and beyond. 


\section{Conflict of interests}

The authors declare no conflict of interest.

\section{References}

1. Andrei, J. V., Popescu, G. H., Nica, E. \& Chivu, L. (2020). The Impact of Agricultural Performance on Foreign Trade Concentration and Competitiveness: Empirical Evidence from Romanian Agriculture. Journal of Business Economics and Management, 21(2), p. 317-343. doi: 10.3846/jbem.2020.11988

2. Balassa, B. (1965). Trade Liberalization and Revealed Comparative Advantage. The Manchester School, 33, p. 99-123

3. Brodowska-Szewczuk, J. (2019). Determinants of the development of enterprises' innovativeness in the aspect of competitiveness of the economy. Entrepreneurship and Sustainability Issues, 7(2), p. 1279-1295. doi: 10.9770/jesi.2019.7.2(33)

4. Ceylan, R. F., Sayin, C., Ozkan, B., Akpinar, M. G. \& Ilbasmis, E. (2018). Comparative advantage analysis for Turkish grape and cherries export market. International Journal of Agriculture, Forestry and Life Science, 2(2), p. 75-86.

5. Đukić, K., Prodanović, R., Čavlin, M. \& Lukač-Bulatović, M. (2020). Economic Performances of Agro-Industry in AP Vojvodina. Oditor, 6(2), p. 7-19 [in Serbian: Ekonomske performanse agroindustrije u AP Vojvodini] doi: 10.5937/ Oditor2002007D

6. Đukić, S., Tomaš-Simin, M. \& Glavaš-Trbić, D. (2018). The Competitiveness of Serbian Agro-Food Sector. Economics of Agriculture, 64(2), p. 723-737. doi: 10.593/ekoPolj1702723D

7. Erlat, G. and Erlat, H. (2012). The Comaparative Advantage of Turkish Exports visà-vis the European Union and OECD Countries, 1990-2000. Ekonomik Yaklasim, 23(1), p. 77-106. doi: 10.5455/ey.20008

8. Gechabia, B., Kharaishvili, E. \& Mushkudiani, Z. (2019). The trends of producing agro-food products and export innovative marketing strategy in Georgia. Economics. Ecology. Socium, 3(3), p. 1-10. doi: 10.31520/2616-7107/2019.3.3-1

9. Granabetter, D. (2016). Revealed Comparative Advantage Index: An Analysis of Export Trade in the Austrian District of Burgenland. Review of Innovation and Competitiveness, 2(2), p. 97-114

10. Grubel, H. and Lloyd, P. (1975). Intra-industry Trade: The Theory and Measurement of International Trade in Differentiated Products. New York: Wiley.

11. Hufbauer, C.G. and Chilas, J.C. (1974). Specialization by Industrial Countries: Extent and Consequences. The International Division of Labor: Problems and Perspectives - International Symposium (ed. by H. Gerisch), Tubinegen, Germany, p. 3-38

12. Ignjatijević, S., Ćirić, M., Đokić, M. \& Kovačević, B. (2013). Structural analysis of international trade on the Danube region countries, Technics Technologies Education Management, 8(1), p. 120-128. 
13. Ignjatijević, S., Vassileva, A., Vapa Tankosić, J., Vapa, B., Ristić, K. \& Mihajlović, M. (2021). Bulgaria's Processed Food Industry - Transition to Market Economy. Economics of Agriculture, 68(1), p. 229-240. doi: 10.5937/ekoPolj2101229I

14. Korableva, O.N., Kalimullina, O.V., Zaytseva, A.A. \& Larionov, A. I. (2018). Elaboration of database for the subject domain of innovation and economic growth potential. $31^{\text {st }}$ International Business Information Management Associattion Conference - IBIMA Proceedings: Innovation Management and Education Excellence through Vision 2020, p. 6065-6073

15. Lafay, G. (1992). The Measurement of Revealed Comparative Advantages in M. G. Dagenais and P. A. Muet (eds). International Trade Modelling, London: Chapman \& Hall.

16. Monaco, F., Zasada, I., Wascher, D., Glavan, M., Pintar, M., Schmutz, U., Mazzocchi, C., Corsi, S. \& Sali. G. (2017). Food production and Consumption: City Regions between Localism, Agricultural Land Displacement, and Economic Competitiveness. Sustainability, 9(1), p. 96. doi: 10.3390/su9010096

17. Poltarykhin, A. L., Alekseev, A. E., Kudryavtsev, V. V., Makhanova, T. A., Voronkova, O. Y., \& Aydinov, H. T. (2018). Prospects for the development of the green economy of russian federation. European Research Studies Journal, 21(4), 470-479. doi: 10.35808/ERSJ/1135

18. Popescu, G, Sima, V., Nica, E. \& Gheorghe, I.G. (2017). Measuring Sustainable Competitiveness in Contemporary Economies - Insights from European Economy. Sustainability, 9(7), p.1230. doi: 10.3390/su9071230

19. Proag, V. (2014). Assessing and Measuring Resilience. Procedia Economic and Finance, 18, p. 222-229. doi: 10.1016/S2212-5671(14)00934-4

20. Rose, A. and Liao, S-Y. (2005). Modeling Regional Economic Resilience to Disasters: A Computable General Equilibrium Analysis of Water Service Disruptions. Journal of Regional Science, 45(1), p. 75-112. doi: 10.1111/j.00224146.2005.00365.x

21. Rutkauskas, V. (2008). On the sustainability of regional competitiveness development considering risk. Technological and Economic Development of Economy, 14(1), p. 88-99. doi: 10.3846/2029-0187.2008.14.89-99

22. Šapić, S., Furtula, S., Durkalić, D., (2018). Prestige and national identity as predictors of food products purchase. Economics of Agriculture, 65 (2), 643-657,. doi: https://doi.org/10.5937/ekoPolj1802643S.

23. Serin, V. \& Civan, A. (2008). Revealed Comparative Advantage and Competitiveness: A Case Study for Turkey towards the EU. Journal of Economic and Social Research, 10(2), p. 25-41.

24. Tasić, J. Geographical and Economic Performance of Organic Agriculture and Tourist Gastronomy in Serbia. Oditor, 4(1), p. 38-51 [in Serbian: Geografske i ekonomske performance organske poljoprivrede i turistička gastronomija u Srbiji] doi: $10.5937 /$ Oditor1801038T 
25. Toming, K. (2006). Accession to the eu: did it boost the export competitiveness of the Estonian food processing industry? University of Tartu - Faculty of Economics \& Business Administration Working Paper Series, 47, p. 3-63.

26. Voronkova, O.Y., Perepechkina, E. G., Shichiyakah, R. A., Kuts, V. I., Sungurov, P. A. \& Glazkova, G. V. (2019). Ecological and Economic Potential and Prospects for Organic Production in the Regions of Russia. International Journal of Economics and Business Administration, 7(1), p. 583-594

27. Vujić, M. ., Đorđević, S. ., \& Lakićević, M. . (2019). Service quality and customer satisfaction in the hotel industry in Serbia. Hotel and Tourism Management, 7(1), 61-70. https://doi.org/10.5937/menhottur1901061V

28. Yilmaz, B. \& Ergun, S. J. (2003). The trade foreign trade pattern and foreign trade specialization of candidates of the European Union (No. 19). Ezoneplus Working Paper. 